Editorial

\title{
Planning for Local Economic Development: Research into Policymaking and Practice
}

\author{
Evan Cleave ${ }^{1, *}$ and Godwin Arku ${ }^{2}$ \\ ${ }^{1}$ Department of Geography and Environmental Studies, Ryerson University, Toronto, M5B 2K3, Canada; \\ E-Mail: evan.cleave@ryerson.ca \\ 2 Department of Geography, University of Western Ontario, London, N6A 3K7, Canada; E-Mail: garku@uwo.ca \\ * Corresponding author
}

Submitted: 22 September 2020 | Published: 29 September 2020

\begin{abstract}
This thematic issue of Urban Planning brings together a collection of seven articles that explore and critically engage with contemporary issues with local economic development and connect with the broader fields of urban development and planning. The articles presented here provide a complementary mix of broader conceptualizations and research and narrower case-studies which draw from a range of geographies. Contributions include the development and application of a vulnerability and risk measures for economic prosperity; examinations of how urban planning and zoning are used as tools to address industrial decline and spur new forms of economic production; complementing investigations into the role of innovation within local economic development examining the role of public and private institutions as well as broad and targeted policy interventions; and the relationship between 'big-tech,' economic development and urban planning and governance.
\end{abstract}

\section{Keywords}

local economic development; planning; policymaking; research and practice

\section{Issue}

This editorial is part of the issue "Planning for Local Economic Development: Research into Policymaking and Practice" edited by Godwin Arku (University of Western Ontario, Canada) and Evan Cleave (Ryerson University, Canada).

(C) 2020 by the authors; licensee Cogitatio (Lisbon, Portugal). This article is licensed under a Creative Commons Attribution 4.0 International License (CC BY).

\section{Introduction}

This thematic issue of Urban Planning examines the current state of local economic development planning and policymaking. Local economic development is no longer focused solely on attraction of large manufacturing facilities (i.e., 'smokestack chasing') and pure wealthgeneration (see Taabazuing, Arku, \& Mkandawire, 2015), nor is it solely managed by local public administrations (Cleave, Arku, \& Chatwin, 2019). Instead, it is a much more holistic process concerned with all aspects of the community beyond the economy-with greater focus on quality of life, effective use of urban space, and service provision (Arku, 2015; Leigh \& Blakely, 2016). This 'new' economic development paradigm also privileges new sectors - such as creative and knowledge industries, advanced manufacturing, and high-tech-as the backbones of future growth. This redefining of local economic development has also emphasized a shift away from traditional, managerial forms of governance towards urban entrepreneurial approaches, where power has been decentralized and engaged by both private and public institutions.

This transition is particularly needed by cities in the advanced economies of Europe and North Americawhere the research presented in this thematic issue is situated. These regions have faced a number of economic challenges over the past half-decade, including increased global competition and stiff competition from new markets (Wolfson \& Frisken, 2000), which has re- 
sulted in the closure of large production facilities and the loss of manufacturing jobs (Cleave, Vecchio, Spilsbury, \& Arku, 2019), declining tax bases and fiscal shortages (Arellano \& Bai, 2017), which have led to severe austerity-focused policies and reduced government capacity (Donald, Glasmeier, Gray, \& Lobao, 2014), greater polarization and disparity within cities (Walks \& Bourne, 2006), and demographic change and stunted population growth in smaller, more peripheral cities (Hall \& Hall, 2008). The impact of these changes is multifaceted, as planners now need to consider what they will do to address these changes, how they will pay for them, and who they will benefit.

The next section introduces the seven articles that form this thematic issue. Despite the range of geographies, methods, and viewpoints on local economic development, there are several thematic and conceptual through-lines, including the connection between local economic development policymaking and urban planning. In addition, many of the articles in this issue contemplate how effectively the issues, policies and approaches they are discussing contribute to fostering positive economic change for the city as a whole.

\section{Overview of the Thematic Issue}

Sadler, Walling, Buchalski, and Harris (2020) provide a comprehensive investigation into the economic vulnerability of 117 mid-sized cities in the Eastern United States through their Prosperity Risk Index for Evaluating Multi-Scalar Economic Development and Equity Patterns (PRIMED) measure. This measure is comprised of municipal fragmentation, geographic sprawl, racial segregation, economic inequality, and overall poverty which have been key nodes of urban research and practice since at least the 1970s. The research being situated in the Eastern United States is important, as the cities in this region have been among the hardest hit by the structural changes to the global economy. Beyond this, the authors' findings present new directions for research, as they identify socio-spatial patterns that deserve further exploration within economic development theory and discourse, as well as potential for identifying at-risk areas requiring policy interventions and evaluation of existing policy and practice.

Situating their research in another region that has experienced considerable economic disruption and transformation, Vecchio and Arku (2020) directly address the interface between economic change and urban planning by asking the following: What are cities doing with their former industrial lands? Framed through a postindustrial lens, the article explores how cities in Ontario, Canada use urban planning-as codified in city master plans-as a tool to confront the impacts of manufacturing decline and to reclaim urban space with an eye towards producing both economic and societal benefits. Of note, the authors find that adaptive reuse is the key strategy cities are using to address issues of affordable housing, intensification, and revitalization-with focus on creating spaces for creative and knowledge-based industries that are vital in the 'new economy.'

This research is complemented by De Boeck and Ryckewaert (2020) who use the narrower case of the Brussels Capital Region, Belgium, to examine how zoning strategies are used to regulate urban space and the implications for places of economic production in the postindustrial city. Their research identifies four key land-use typologies and finds that industrial gentrification is occurring in three of these. Interestingly, this is a dynamic process as gentrification both fills spaces in Brussels where deindustrialization has occurred, but also driven further decline through displacement of industrial and commercial land. A key contribution is that different institutions play different roles across the city-public authorities driving change in industrial zones and private actors facilitating land-use conversions in mixed-use areas. This suggests that there is currently a tenuous balance of actors driving development of spaces of production within cites, with the planners and the public being locked-out of decision-making in how large swaths of the city will be developed. This has strong implications for understanding urban governance and land use planning in post-industrial cities.

Phan, Cleave, and Arku (2020), is one of two articles in this issue that explores the role of innovation within local economic development. Here, the authors frame local governments and economic development practitioners as key institutions responsible for facilitating innovation. Using interviews with city officials from across Ontario, Canada, the authors critically examine how cities approach innovation and what they are actually doing to foster it. Despite its prevalence within economic policy, Phan et al. (2020) find that innovation varies considerably in conception across cities. Despite this, the article finds that there is actually considerable homogeneity in the approaches being implemented. This is a key finding with practical implications, as it suggests that cities are not being efficient in their approaches to planning or creating a local context with the determinants of innovation needed for emerging innovationcentric sectors to establish and thrive.

Zandiatashbar and Kayanan (2020) use examples from three American cities (Boston, MA, St. Louis, MO, and Buffalo, NY) to focus on a specific place-based innovation planning policy: Innovation Igniting Urban Developments. Complementing Phan et al. (2020), this article focuses both on the role of public/private urban growth coalitions play on these developments and on their impact on urban spaces. A key finding that emerges from these authors' work is the increased polarization that these spatially target strategies cause within cities.

Sands, Filion, and Reese (2020) explore the emphasis on services and investment in human capital through the examination of Amazon's proposed HQ2 in New York City and the Sidewalk Labs' Quayside proposal for the City of Toronto. Their examination of the two projects demon- 
strates that even if the target has changed from manufacturing to 'big tech,' the playbook local governments are using to entice them-incentives and tax-breakshas not. This, the authors argue, is problematic as the incentivization within this traditional approach to business attraction is beyond the means of most cities. A striking conclusion of this research is 'big tech's' role within local economic development does not help 'lift up' distressed areas, but rather privileges "wealthy cities, to wealthy firms, for the benefit of wealthy residents" creating increased potential for economic disparity (Sands et al., 2020, p. 400).

Braumann (2020) provides an interesting extension of this research through a comprehensive summary and critical examination of the HQ2 competition, through an exhaustive examination of Amazon's site selection criteria. This article refocuses away from the city and planning to that of business-asking what location factors are important to them. The findings here complement those in Sands et al. (2020), as they suggest that for 'big-tech' the desired characteristics of a city preclude all but the largest and wealthiest places. Braumann (2020), however, makes an interesting connection with broader urban planning in his identification of 'project-oriented' location-decision factors which focus on suitability, expandability, and feasibility of managing and transforming urban space so it meets the needs of the Amazon HQ2 project. Generalizing the work, urban planning has to consider current and future needs of companies and integrate these into larger business and investment attraction strategies.

\section{Future Research and Conclusions}

Local economic development is a broad field, and the research presented here-while substantive-only scratches its surface. There are many directions that can emerge from the research presented here to ensure that local economic development can occur in a way that takes a holistic view, where efforts are made to address issues of entire cities to reduce disparity and exclusion and raise the overall quality of life for all residents. This is a challenge, in part, due to the multitude of issues cities in North America and Europe have and continue to face. Within the comprehensive research presented here, however, the authors discuss ways to turn research into practice, and identify key strategies or pathways to better local economic development. It is hoped that the contributions of this thematic issue stimulate new ideas for research and practical solutions to issues facing cities globally.

\section{Acknowledgments}

The editors would like to express their sincere gratitude to the authors, peer-reviewers, and editorial staff at Urban Planning. Without their efforts, this thematic issue would not be possible. The editor Evan Cleave would also like to thank his co-editor, Dr. Godwin Arku, for his considerable effort in helping to organize this thematic issue.

\section{Conflict of Interests}

The authors declare no conflict of interests.

\section{References}

Arellano, C., \& Bai, Y. (2017). Fiscal austerity during debt crises. Economic Theory, 64(4), 657-673.

Arku, G. (2015). Economic development practices of cities in Ontario. Community Development, 46(5), 604-615.

Braumann, A. (2020). Amazon's HQ2 site selection criteria: The new 'gold standard' in FDI decision-making. Urban Planning, 5(3), 403-417.

Cleave, E., Arku, G., \& Chatwin, M. (2019). One step forward, two steps back? Examining the influence of consultants on local economic development policy. Canadian Public Administration, 62(1), 96-121.

Cleave, E., Vecchio, E., Spilsbury, D., \& Arku, G. (2019). Manufacturing change and policy response in the contemporary economic landscape: How cities in Ontario, Canada, understand and plan for manufacturing. Regional Studies, Regional Science, 6(1), 469-495.

De Boeck, S., \& Ryckewaert, M. (2020). The preservation of productive activities in Brussels: The interplay between zoning and industrial gentrification. Urban Planning, 5(3), 351-363.

Donald, B., Glasmeier, A., Gray, M., \& Lobao, L. (2014). Austerity in the city: Economic crisis and urban service decline? Cambridge Journal of Regions, Economy and Society, 7(1), 3-15.

Hall, H., \& Hall, P. (2008). Decline and no growth: Canada's forgotten urban interior. Canadian Journal of Regional Science, 31(1), 39-57.

Leigh, N., \& Blakely, E. (2016). Planning local economic development: Theory and practice (6th ed.). Washington, DC: Sage.

Phan, S., Cleave, E., \& Arku, G. (2020). Innovation within the context of local economic development and planning: Perspectives of city practitioners. Urban Planning, 5(3), 364-377.

Sadler, R., Walling, D., Buchalski, Z., \& Harris, A. (2020). Are metropolitan areas primed for success? A prosperity risk index for evaluating economic development patterns. Urban Planning, 5(3), 323-337.

Sands, G., Filion, P., \& Reese, L. A. (2020). Techs and the cities: A new economic development paradigm? Urban Planning, 5(3), 392-402.

Taabazuing, M., Arku, G., \& Mkandawire, P. (2015). Economic development in a changing global environment: What do practitioners think? Urban Research and Practice, 8(2), 145-164.

Vecchio, M., \& Arku, G. (2020). Promoting adaptive reuse 
in Ontario: A planning policy tool for making the best of manufacturing decline. Urban Planning, 5(3), 338-350.

Walks, R. A., \& Bourne, L. (2006). Ghettos in Canada's cities? Racial segregation, ethnic enclaves and poverty concentration in Canadian urban areas. The Canadian Geographer, 50(3), 273-297.

Wolfson, J., \& Frisken, F. (2000). Local response to the global challenge: Comparing local economic development policies in a regional context. Journal of Urban Affairs, 22(4), 361-384.

Zandiatashbar, A., \& Kayanan, C. M. (2020). Negative consequences of innovation-igniting urban developments: Empirical evidence from three US cities. Urban Planning, 5(3), 378-391.

\section{About the Authors}

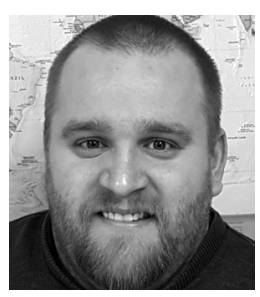

Evan Cleave is an Assistant Professor in the Department of Geography and Environmental Studies at Ryerson University (Toronto, Canada). His research focuses on urban and local economic development policy and planning, including how and why policy is formulated by local governments, as well as its effectiveness in addressing local challenges. His research also focuses on issues related to place branding and marketing.

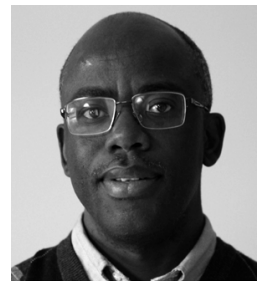

Godwin Arku is an Associate Professor in the Department of Geography at the University of Western Ontario (London, Canada). His research examines local impacts and community responses to global economic, social, and environmental changes. Within this field, he looks at issues such as local impacts and policy responses to plant closures, municipal economic development policies, transnationalism, and immigrant housing, impacts of economic liberalization on housing markets, and economic reforms and built environment changes. 